\title{
Analisis Kebutuhan Media Promosi Kesehatan Layanan Provider Initiated Testing and Counseling (PITC) bagi Ibu Hamil
}

\author{
Lenna Maydianasari ${ }^{1}$ dan Ester Ratnaningsih ${ }^{2}$ \\ 1,2Program Studi Kebidanan, Program Sarjana, Universitas Respati Yogyakarta \\ lenna@respati.ac.id ${ }^{1}$, esterratna@respati.ac.id ${ }^{2}$
}

\begin{abstract}
Diajukan 27 November 2020 Diperbaiki 10 Februari 2021 Diterima 12 Februari 2021 ABSTRAK
\end{abstract}

Latar Belakang: Kasus HIV pada ibu hamil di Kabupaten Sleman pada tahun 2018 sebanyak 23 kasus dan meningkat menjadi 75 kasus pada tahun 2019. Setiap ibu hamil sudah diwajibkan untuk dilakukan tes HIV melalui layanan PITC. Namun, media promosi kesehatan tentang layanan PITC belum tersedia, sehingga ibu hamil belum memahami pentingnya layanan tersebut dan pencegahan HIV/AIDS.

Tujuan: Untuk menganalisis kebutuhan media promosi kesehatan layanan PITC bagi ibu hamil.

Metode: Penelitian ini merupakan penelitian penjelasan (explanatory research) dengan pendekatan kuantitatif untuk meneliti karaktersitik responden dan informasi layanan PITC serta pendekatan kualitatif untuk kebutuhan media promosi kesehatan layanan PITC. Teknik pengumpulan data dengan kuesioner dan panduan wawancara mendalam. Analisis data menggunakan analisis deskriptif dan analisis isi (content analysis).

Hasil: Mayoritas responden berusia 20-35 tahun, pendidikan menengah, ibu rumah tangga, primigravida dan umur kehamilan trimester III. Media promosi kesehatan layanan PITC diperlukan untuk mempermudah penyampaian informasi bagi ibu hamil dan suaminya $(51,7 \%)$. Bentuk pesan dan media yaitu audiovisual $(87,1 \%)$ dan jenis media sosial $(75,3 \%)$.

Kesimpulan: Media promosi kesehatan layanan PITC bagi ibu hamil yang dibutuhkan adalah media audiovisual yang disampaikan melalui media sosial. Media tersebut dapat diintegrasikan dengan strategi promosi serta komunikasi kesehatan efektif untuk pencegahan HIV/AIDS pada kehamilan.

Kata Kunci: kebutuhan; media; promosi; PITC

\section{ABSTRACT}

Background: The number of HIV cases among pregnant women in Sleman Regency in 2018 was 23 and it increased to 75 in 2019. Every pregnant woman is required to have HIV test through PITC service. However, there is no health promotion media on PITC service, so that pregnant women don't understand the importance of the service and HIVIAIDS prevention.

Objective: To analyze the demand for PITC service health promotion media for pregnant women.

Method: This was an explanatory research with quantitative approach to study respondent's characteristics and PITC service information, as well as qualitative approach for the demand for PITC service health promotion media. The data collection techniques were questionnaire and in-depth guided interview. The data analysis used descriptive analysis and content analysis.

Results: The majority of the respondents were 20-35 years-old, had moderate education, were housewives, primigravida, and were in the 3rd trimester. PITC service health promotion media were required to deliver information to pregnant women and their husbands (51.7\%). The message and media were audiovisual $(87.1 \%)$ and social media type (75.3\%).

Conclusion: The required PITC service health promotion media for pregnant women are audiovisual media delivered via social media. The media can be integrated with promotional strategy and effective health communication to prevent HIVIAIDS during pregnancy.

Keywords: demand; media; promotion; PITC 
PENDAHULUAN

Jumlah kasus HIV/AIDS di Indonesia masih terus meningkat, angka nasional sampai Januari 2019 tercatat berjumlah 326.281 kasus. Demikian halnya dengan epidemi HIV/AIDS di Daerah Istimewa Yogyakarta (DIY) masih berlanjut. Data pada bulan Desember 2019 menunjukkan tercatat 5.264 kasus HIV dan 1.726 masuk tahap AIDS (Pemda DIY, 2019). Dari jumlah kasus HIV di DIY, paling banyak ditemukan pada penduduk usia 20-29 tahun dan paling sedikit ditemukan pada penduduk usia lebih dari 60 tahun. Namun demikian, kasus HIV-AIDS juga masih ditemukan pada bayi usia kurang dari 1 tahun. Hal ini menunjukkan bahwa penularan HIV-AIDS dari ibu ke bayi masih terjadi di DIY (Dinkes DIY, 2020).

Program nasional menargetkan pada tahun 2030 tercapai three zero, yaitu tidak ada infeksi baru HIV (zero new infection), tidak ada kematian akibat AIDS (zero AIDS related deaths) dan tidak ada stigma dan diskriminasi kepada penderita HIVAIDS (zero discrimination) (Rokom, 2019). Pengendalian HIV/AIDS bertujuan untuk meningkatkan jumlah orang yang mengetahui status HIVnya sehingga yang mengidap positif HIV mendapatkan layanan kesehatan lebih dini. Upaya tersebut adalah layanan konseling dan tes HIV atas prakarsa petugas kesehatan (TIPK) atau Provider Initiated Testing and Counseling (PITC) disamping menguatkan layanan konseling dan testing HIV secara sukarela (KTS/VCT) (Kemenkes RI, 2020).

Sejalan dengan upaya tersebut, Dinkes DIY telah menyiapkan 161 layanan kesehatan tingkat dasar dan lanjutan untuk memberikan pelayanan tes HIV serta layanan lanjutan. Selain itu juga, diprogramkan setiap ibu hamil untuk diperiksa HIV (Dinkes DIY, 2019). Kasus HIV di DIY paling banyak ditemukan di Kabupaten Sleman dibandingkan kabupaten/kota lainnya. Tahun 2018 tercatat 915 kasus, sedangkan di Kota Yogyakarta 859 kasus, Kabupaten Bantul
857 kasus dan paling sedikit 201 kasus di Kabupaten Kulon Progo . Oleh karena itu, PITC sudah menjadi program wajib khususnya bagi semua ibu hamil di Kabupaten Sleman, namun cakupannya belum mencapai $100 \%$. Kasus HIV pada ibu hamil di Kabupaten Sleman pada tahun 2018 ditemukan sebanyak 23 kasus terdiri dari ibu hamil datang dengan HIV positif sejumlah 8 orang dan ibu hamil dengan hasil tes HIV reaktif sebanyak 15 orang. Jumlah kasus tersebut meningkat menjadi 75 kasus pada tahun 2019, dimana ibu hamil datang dengan HIV positif sebanyak 55 orang dan ibu hamil dengan hasil tes HIV reaktif sebanyak 20 orang (Dinkes DIY, 2020).

Minimnya informasi serta pelayanan kesehatan yang kurang optimal menyebabkan kasus HIV/AIDS meningkat setiap tahun. Masalah ini memerlukan penanganan lebih serius dari berbagai pihak terkait, termasuk tenaga kesehatan yang perlu ditingkatkan peran dan kontribusinya (Pudjiati, 2016). Dengan demikian, peran media sangat diperlukan di dalam pelaksanaan promosi kesehatan untuk dapat mempermudah penyampaian informasi tersebut. Media promosi kesehatan yang tepat sesuai kebutuhan akan lebih menarik dan dipahami, sehingga sasaran dapat mempelajari pesan yang disampaikan, kemudian akan memutuskan untuk mengadopsi perilaku yang positif (Notoatmodjo, 2010).

Di era digital saat ini, promosi kesehatan mulai menggunakan berbagai aplikasi. Namun, sampai saat ini belum ada media promosi kesehatan tentang layanan PITC yang efektif untuk meningkatkan minat ibu hamil memanfaatkan layanan PITC di Kabupaten Sleman. Oleh karena itu, perlu dianalisis kebutuhan media promosi yang tepat sasaran untuk meningkatkan minat ibu hamil memanfaatkan layanan PITC. Aspek kebutuhan media promosi layanan PITC bagi ibu hamil yang akan dianalisis disesuaikan dengan langkah-langkah 
Analisis Kebutuhan Media Promosi Kesehatan...

merancang media promosi kesehatan menurut Agustini (2014), yaitu menetapkan tujuan, menetapkan segmentasi sasaran, memposisikan pesan (positioning), menentukan strategi positioning dan memilih media promosi kesehatan .

\section{METODE}

Penelitian ini merupakan penelitian penjelasan (explanatory research). Pendekatan yang digunakan pada penelitian ini yaitu pendekatan kuantitatif yang kemudian dikombinasikan dengan kualitatif (Mixed Method). Pendekatan kuantitif menggunakan rancangan crosssectional untuk meneliti karakteristik responden dan informasi tentang layanan PITC, sedangkan aspek kebutuhan media promosi kesehatan tentang layanan PITC bagi ibu hamil diteliti dengan pendekatan kuantitatif serta pendekatan kualitatif menggunakan rancangan studi fenomenologi. Penelitian dilaksanakan di Puskesmas Depok II, Kabupaten Sleman, pada tanggal 29 Juli-11 September 2020. Populasi dalam penelitian ini adalah seluruh ibu hamil yang melakukan pemeriksaan kehamilan (ANC) di Puskesmas Depok II. Jumlah sampel penelitian ini sebanyak 85 ibu hamil yang memeriksakan kehamilannya di Puskesmas Depok II dengan teknik sampling yang digunakan adalah accidental sampling. Dalam penelitian ini dilakukan triangulasi sumber dengan metode kualitatif dengan sampel diambil secara purposive sampling. Triangulasi sumber dalam penelitian ini untuk mengecek data kuantitatif yang dilakukan kepada 4 informan, yaitu 2 staf Puskesmas Depok II dan 2 staf Dinas Kesehatan Kabupaten Sleman.

Instrumen penelitian ini yaitu kuesioner analisis kebutuhan media promosi kesehatan layanan PITC bagi ibu hamil dan panduan wawancara mendalam. Instrumen yang digunakan telah dilakukan uji validitas kontruksi (construct validity) menggunakan pendapat ahli (judgment experts). Pengumpulan data kuantitatif penelitian ini menggunakan instrumen kuesioner yang diberikan kepada ibu hamil yang berkunjung ke Puskesmas Depok II untuk memeriksakan kehamilannya. Pengumpulan data kualitatif dilakukan dengan wawancara mendalam (indepth interview) yang dilakukan setelah data kuantitatif dianalisis. Dalam penelitian ini analisis kuantitatif dilakukan dengan analisis deskriptif setiap item jawaban dari pertanyaan kuesioner dan analisis kualitatif bersifat terbuka yang menggunakan proses induktif. Analisis data dilakukan dengan cara deskriptif isi (content analysis).

\section{HASIL DAN PEMBAHASAN}

Tabel 1. Distribusi Frekuensi dan Persentase Karakteristik Responden

\begin{tabular}{|c|c|c|c|}
\hline No. & Karakteristik & f $n=85$ & $\%$ \\
\hline \multirow[t]{4}{*}{1} & Umur & & \\
\hline & $<20$ tahun & 3 & 3 \\
\hline & 20-35 tahun & 74 & 74 \\
\hline & $>35$ tahun & 8 & 8 \\
\hline \multirow[t]{4}{*}{2} & Tingkat Pendidikan & & \\
\hline & Rendah & 9 & 10,6 \\
\hline & Menengah & 43 & 50,6 \\
\hline & Tinggi & 33 & 38,8 \\
\hline \multirow[t]{6}{*}{3} & Pekerjaan & & \\
\hline & IRT & 54 & 63,5 \\
\hline & PNS/ PORI & 4 & 4,8 \\
\hline & Swasta & 16 & 18,8 \\
\hline & Wiraswasta & 8 & 9,4 \\
\hline & Mahasiswa & 3 & 3,5 \\
\hline \multirow[t]{4}{*}{4} & Jumlah kehamilan & & \\
\hline & Primigravida & 44 & 51,8 \\
\hline & Multigravida & 40 & 47,0 \\
\hline & Grandemultigravida & 1 & 1,2 \\
\hline \multirow[t]{4}{*}{5} & Umur kehamilan & & \\
\hline & Trimester I & 23 & 27,1 \\
\hline & Trimester II & 29 & 34,1 \\
\hline & Trimester III & 33 & 38,8 \\
\hline
\end{tabular}

Tabel 1 menunjukkan bahwa mayoritas responden berusia 20-35 tahun $(87,1 \%)$, sebagian besar berpendidikan menengah $(50,6 \%)$ dan mayoritas adalah ibu rumah tangga (63,5\%). Berdasarkan jumlah kehamilan, sebagian besar responden adalah primigravida (51,8\%) dan umur kehamilan responden 
terbanyak adalah trimester III (38,8\%).

Berdasarkan tabel 2 dapat diketahui bahwa mayoritas responden belum pernah mendapatkan informasi tentang layanan PITC (50,6\%). Sebagian besar responden tertarik terhadap informasi PITC $(90,6 \%)$ dan paling banyak sumber informasi tentang layanan PITC didapatkan dari media sosial $(34,6 \%)$ dibandingkan dari petugas kesehatan (23,1\%). Hal tersebut sesuai dengan pendapat Korda \& Itani (2013) yang menyebutkan bahwa media sosial dapat meningkatkan akses masyarakat untuk mendapatkan informasi kesehatan karena memiliki jangkauan dan interaktivitas yang luas.

Tabel 2. Distribusi Frekuensi dan Persentase Informasi tentang Layanan PITC

\begin{tabular}{|c|c|c|c|}
\hline \multicolumn{4}{|c|}{ No. Informasi layanan PITC } \\
\hline \multirow{4}{*}{1} & Pengalaman Mendapat & & \\
\hline & Informasi & & \\
\hline & Pernah & 42 & 49,4 \\
\hline & Belum Pernah & 43 & 50,6 \\
\hline \multirow[t]{3}{*}{2} & Ketertarikan Informasi & & \\
\hline & Tertarik & 77 & 90,6 \\
\hline & Tidak Tertarik & 8 & 9,4 \\
\hline \multirow[t]{7}{*}{3} & Sumber Informasi & & \\
\hline & Petugas kesehatan & 30 & 23,1 \\
\hline & Teman & 16 & 12,3 \\
\hline & Keluarga & 9 & 6,9 \\
\hline & Media Sosial & 45 & 34,6 \\
\hline & Media Massa & 13 & 10 \\
\hline & Media Elektronik & 17 & 13,1 \\
\hline
\end{tabular}

Tabel 3. Hasil Analisis Kebutuhan Media Promosi Kesehatan Layanan PITC Bagi Ibu Hamil

\begin{tabular}{|c|c|c|c|}
\hline No. & Hasil Analisis & $f \mathbf{n}=85$ & $\%$ \\
\hline \multicolumn{4}{|c|}{1 Kebutuhan } \\
\hline & Perlu & 83 & 97,6 \\
\hline & Tidak perlu & 2 & 2,4 \\
\hline \multirow[t]{4}{*}{2} & Tujuan & & \\
\hline & $\begin{array}{l}\text { a. Mempermudah } \\
\text { penyampaian informasi }\end{array}$ & 43 & 50,6 \\
\hline & $\begin{array}{l}\text { b. Membuat pesan mudah } \\
\text { dipahami }\end{array}$ & 15 & 17,6 \\
\hline & $\begin{array}{l}\text { c. Menghindari salah } \\
\text { pengertian }\end{array}$ & 27 & 31,8 \\
\hline \multirow[t]{5}{*}{3} & Sasaran & & \\
\hline & a. Suami Ibu Hamil & 12 & 14,1 \\
\hline & b. Ibu Hamil & 13 & 15,3 \\
\hline & c. Orang Tua Ibu Hamil & 1 & 1,2 \\
\hline & d. Suami dan Ibu Hamil & 44 & 51,7 \\
\hline
\end{tabular}

e. Suami dan Orang tua

f. Ibu Hamil dan Orang tua

g. Suami, Ibu hamil dan Orang Tua

4 Cara efektif memahami informasi kesehatan
a. Individu
b. Kelompok
c. Masyarakat

5 Informasi yang dibutuhkan

\begin{tabular}{|c|c|}
\hline a. Pengertian layanan & 2 \\
\hline b. Manfaat layanan & 9 \\
\hline $\begin{array}{l}\text { c. Cara memanfaatkan } \\
\text { layanan }\end{array}$ & 20 \\
\hline Tahapan layanan & \\
\hline Pengertian, manfaat, & 49 \\
\hline
\end{tabular}
cara memanfaatkan dan tahapan layanan

6 Bentuk pesan
a. Tulisan
$2 \quad 2,4$
b. Gambar dan tulisan
c. Gambar, tulisan dan

7 Media promkes yang pernah dilihat

$\begin{array}{lcc}\text { a. Selebaran } & 43 & 20,3 \\ \text { b. Poster } & 40 & 18,9 \\ \text { c. Flyer } & 29 & 13,7 \\ \text { d. Booklet } & 16 & 7,5 \\ \text { e. Majalah } & 19 & 9 \\ \text { f. Baliho } & 33 & 15,5 \\ \text { g. Lembar Balik } & 6 & 2,8 \\ \text { h. Video } & 21 & 9,9 \\ \text { i. Film } & 5 & 2,4\end{array}$

8 Alasan ketertarikan melihat media promkes a. Tulisan jelas $\quad 14 \quad 16,5$

b. Gambar menarik $\quad 12 \quad 14,2$

c. Tempat pemasangan $15 \quad 17,6$ strategis d. Informasi yang

9 Bentuk media promkes yang mudah dipahami

$\begin{array}{lll}\text { a. Visual } & 11 & 12,9 \\ \text { b. Audiovisual } & 74 & 87,1 \\ \text { Jenis media } & & \\ \text { a. Cetak } & 10 & 11,8 \\ \text { b. Elektronik } & 11 & 12,9 \\ \text { c. Sosial } & 64 & 75,3\end{array}$

Sebagian besar responden menganggap perlu adanya media promosi kesehatan tentang layanan PITC bagi ibu hamil $(97,6 \%)$. Hal ini diperkuat dengan ketertarikan yang besar terhadap informasi PITC (90,6\%). Hasil wawancara mendalam menunjukkan bahwa media promosi kesehatan tentang layanan tes 
dan konseling HIV/AIDS di Puskesmas Depok II sangat diperlukan, karena media yang sudah ada sasarannya masih umum belum spesifik kepada ibu hamil dan belum adanya kesadaran ibu hamil mengetahui tentang PITC walaupun pemeriksaan sudah dilakukan pada saat ANC terpadu.

Perlu ya..karena selama ini media kita justru sasarannya banyak yang umum, belum spesifik ibu hamil (Ny.BS, 25 tahun)

Memang sangat diperlukan ya..karena selama ini kesadaran ibu hamil masih belum untuk mengetahui PITC..eee jadi mereka diperiksa tapi belum tahu itu buat apa (Ny.AA, 36 tahun)

Informasi tentang layanan PITC ini diperlukan karena sebagian besar ibu hamil dalam penelitian ini belum pernah mendapatkan informasi tentang layanan PITC (50,6\%), dimana mayoritas responden primigravida (hamil pertama), sehingga belum mendapatkan pengalaman maupun pengetahuan tentang PITC pada kehamilan sebelumnya. Walaupun layanan PITC ini diwajibkan bagi semua ibu hamil, namun kenyataannya ibu hamil belum memiliki pengetahuan tentang layanan tersebut dan pencegahan penularan HIV/AIDS. Pada penelitian Ajzen et al. (2011), menyebutkan bahwa pengetahuan tentang HIV/AIDS adalah prasyarat yang diperlukan untuk berbagai perubahan perilaku dalam pencegahan HIV/AIDS pada populasi berisiko. Pengetahuan ibu hamil tentang penularan HIV/AIDS dari ibu ke bayinya serta pencegahannya memiliki hubungan positif dengan sikap ibu hamil terhadap PITC (Abtew et al., 2016; Ajzen et al., 2011).

Mayoritas responden menyatakan tujuan media promosi layanan PITC adalah untuk mempermudah penyampaian informasi $(50,6 \%)$. Setelah ibu hamil mengetahui tentang penyakit
HIV ini, maka risiko penularan dari ibu hamil yang positif HIV ke bayinya dan kematian ibu bisa dicegah dengan terapi antiretroviral (ARV) dan penanganan lainnya.

Yang pertama untuk mencegah penularan ke bayi juga mencegah kematian ibunya ya..dan yang penting kalau ibunya HIV si bayi bisa mendapatkan $A R V$ atau penanganan lainnya ya (Ny.AA, 36 tahun)

Hal tersebut didukung dengan pendapat Notoatmodjo (2010) yang menyebutkan bahwa media dapat berfungsi untuk membantu dalam mengatasi banyak hambatan dalam pemahaman seseorang, mempermudah penyampaian bahan atau informasi kesehatan dan mempermudah penerimaan informasi oleh sasaran/ masyarakat. Jika ibu hamil sudah mengetahui tentang penyakit HIV, maka risiko penularan dari ibu hamil yang positif HIV ke bayinya dan kematian ibu bisa dicegah dengan terapi antiretroviral (ARV) dan penanganan lainnya. World Health Organization (WHO) menegaskan bahwa sumber infeksi HIV yang paling signifikan pada anak-anak dan bayi adalah penularan HIV dari ibu ke anak selama kehamilan, melahirkan, atau menyusui. Tanpa intervensi, risiko penularan bervariasi mulai dari 5\% hingga $10 \%$ selama kehamilan, $10 \%$ hingga $15 \%$ selama persalinan dan 5\%$20 \%$ melalui menyusui (WHO, 2015).

Sebagian besar responden menyatakan sasaran media promosi layanan PITC adalah suami dan ibu hamil (51,7\%). Selain itu, informan menambahkan sasarannya adalah keluarga ibu hamil yang setiap hari tinggal bersama ibu hamil, seperti ibu dari ibu hamil tersebut (nenek). Peran keluarga ini diharapkan dapat memberikan dukungan kepada ibu hamil. 
Yaa..untuk suami atau pasangannya..karena kadang kalau pas periksa sama suaminya kita tawari tes HIV suaminya kaya gimana gitu, jadinya pengetahuannya enggak cuma untuk ibu hamil tapi medianya kalau bisa manfaatnya juga untuk suaminya...selain itu juga orang tuanya yang setiap hari tinggal dengan ibu hamil (Ny.BS, 25 tahun)

Cara penyampaian informasi kesehatan yang paling efektif dilakukan secara individu (56,5\%). Informan menyebutkan bahwa cara yang efektif bagi ibu hamil untuk memahami informasi kesehatan adalah konseling individu karena informasi langsung tersampaikan dan lebih mengena. Selain itu, konseling individu lebih privacy bagi ibu hamil untuk menyampaikan keluhan yang dirasakan. Hal ini didukung oleh Notoatmodjo (2010) yang menyebutkan bahwa pendidikan kesehatan dengan metode individu didasari adanya masalah dan alasan setiap orang berbeda. Dengan metode individu, petugas kesehatan lebih tepat menyampaikan informasi sesuai masalah atau kebutuhan setiap orang. Metode ini digunakan untuk membina sesseorang yang tertarik kepada suatu perubahan perilaku atau inovasi.

Saya rasa kalau individu lebih efektif ya karena langsung tersampaikan dan lebih mengena dibandingkan kalau lewat kader nanti informasinya nanti jadi berbeda ya..walaupun masyarakat juga perlu tahu ya (Ny.BP, 51 tahun)

Sebenernya semua itu bisa ditangkap, cuma lebih bagusnya konseling individu sih..karena pengalaman kalau penyuluhan di masyarakat, biasanya kita di posyandu malah enggak masuk, ibu hamilnya dengerin aja tapi kurang efektif karena rame keadaannya, selain itu kalau ada keluhan seperti HIV dia juga enak menyampaikannya, selain itu kalau konseling individu lebih jujur..kalau kelas ibu hamil sama seperti tadi privacynya kurang (Ny.BS, 25 tahun)
Isi informasi layanan PITC terbanyak dibutuhkan adalah pengertian, manfaat, cara memanfaatkan dan tahapan layanan PITC (57,6\%). Selain itu informasi yang penting diketahui ibu hamil yaitu tentang bahaya/risiko penyakit HIV/AIDS pada kehamilan, cara penularan termasuk siapa saja yang bisa tertular dan pencegahannya, manfaat tes dan konseling HIV/AIDS (PITC) serta penanganan penderita termasuk peluang kesembuhan.

Yang harus dipahami dari isi media itu yaitu apa itu HIV kemudian bagaimana cara penularannya, ada dimana saja, bagaimana cara mencegahnya dan siapa saja yang bisa tertular HIV dan apakah HIV bisa disembuhkan nah itu banyak sekali yang jadi mitos-mitos di masyarakat sehingga kalau ada yang positif tidak sesuai dengan protokol $A R V$ (Tn.AP, 51 tahun)

Kebutuhan informasi tentang layanan PITC tersebut seharusnya sudah diperoleh ibu hamil saat konseling sebelum dilakukan tes HIV (pre counseling) sebagai bagian dari prosedur PITC. Namun kenyataannya karena pemeriksaan ini wajib dilakukan kepada semua ibu hamil, maka pemberian konseling ini tidak lagi diprioritaskan untuk dilakukan oleh tenaga kesehatan. Penelitian Novika \& Setyaningsih (2019) menunjukkan bahwa konseling sebelum tes HIV yang dilaksanakan oleh bidan baru terbatas pada pengisian format dan belum dilaksanakan konseling secara menyeluruh tentang HIV/AIDS dikarenakan keterbatasan waktu dan banyaknya data yang harus dikaji. Ibu hamil belum mendapatkan penjelasan lengkap tentang HIV/AIDS dan diminta langsung menandatangani lembar persetujuan. Sumitri \& Darmayanti (2019) menambahkan bahwa hambatan dalam konseling HIV/AIDS pada ibu hamil adalah tidak tersedianya fasilitas ruangan untuk konseling yang memadai. 
Jenis pesan informasi yang paling banyak mudah dipahami adalah berupa gambar, tulisan dan suara $(60 \%)$. Selain itu, pesan juga harus dengan bahasa yang sederhana, tidak menggunakan kata-kata medis dan mudah dipahami masyarakat seperti pesan yang bisa dilihat dan didengar (audiovisual) agar mudah dipahami. Hal ini didukung oleh Ahmadi \& Ibda (2018) yang menyebutkan bahwa pesan audiovisual memiliki kelebihan karena dapat menarik perhatian pada periode yang singkat dibandingkan jenis pesan lainnya.

Saya rasa pesan yang sederhana..tidak perlu menggunakan kata-kata medis, yang biasa digunakan masyarakat saja (Ny.BP, 51 tahun)

Jenis media promosi kesehatan yang pernah responden lihat paling banyak adalah media selebaran/leaflet (20,3\%). Senada dengan hal tesebut, informan menambahkan bahwa media promosi kesehatan yang sering digunakan yaitu poster dan leaflet HIV/AIDS, secara umum belum spesifik untuk ibu hamil dan leaflet tentang triple eliminasi serta lembar balik. Media lainnya seperti animasi dan videovideo tentang informasi HIV diunduh dari website Kemenkes RI.

Biasanya pakai leaflet...terus kemudian ada lembar balik (Ny.BP, 51 tahun)

Itu kita punya poster juga leaflet kalau leaflet yang sudah ada masih HIVIAIDS secara umum..belum khusus ibu hamil, kalau videovideo tentang HIV kita download dari Kemenkes (Ny.BS, 25 tahun)

Leaflet memiliki keunggulan dapat disimpan dalam jangka waktu yang lama dan bila lupa bisa dilihat kembali. Selain itu isi informasi dapat dipercaya karena biasanya dicetak oleh instansi berwenang sehingga jangkauan media ini bisa lebih jauh bahkan dapat membantu media lainnya, bakan bila ada kebutuhan lebih banyak bisa dicetak ulang. Akan tetapi, leaflet juga memiliki kelemahan yaitu apabila cetakannya kurang menarik perhatian, tulisan terlalu kecil sehingga susah dibaca apalagi bagi sasaran yang buta huruf, media ini tentu saja tidak bisa digunakan untuk menyampaikan informasi kesehatan.

Lain halnya dengan poster, kelebihannya yaitu dapat ditempel/ dipasang dimana-mana, sehingga memudahkan sasaran promosi kesehatan untuk memahami kembali informasi kesehatan dan menyarankan perubahan tingkah laku sasaran yang melihatnya. Akan tetapi, kelemahan media ini adalah mudah rusak, misalnya karena hujan atau justru dirusak, selain itu juga untuk tampilan poster yang menarik perlu ahli grafis dan peralatan cetak yang biayanya tidak murah (Siregar et al., 2020).

Hal yang menarik responden dalam membaca media informasi yakni manfaat yang disampaikan, penting (51,7\%). Dari sisi penggunaan media, hal yang membuat tertarik untuk menggunakan media promosi kesehatan adalah karena bahasanya sederhana serta ada gambargambar yang memudahkan untuk menyampaikan pesan kesehatan, serta bisa dibaca kapan saja. Selain itu, ketertarikan menggunakan media juga karena pertimbangan lebih privacy.

Ya mungkin karena disitu bahasanya sederhana dan ada gambar-gambarnya gitu..kalau di lembar balik itu kan sudah ada penjelasan gambar-gambarnya sehingga bisa kita tambahi kata-katanya (Ny.BP, 51 tahun)

Mungkin karena leaflet bahasanya lebih sederhana..leaflet biasanya juga bisa dibaca kapan saja ya (Ny.AA, 36 tahun)

Kalau media promosinya kalau saya lebih senang dengan lembar balik kalau ada yang menjurus pribadi kita pakai lembar balik sehingga kita pakai lembar balik (Tn.AP, 51 tahun) 
Bentuk media promosi kesehatan yang paling mudah dipahami adalah media yang dapat didengar dan dilihat (audiovisual) $(87,1 \%)$ seperti video. Hal ini didukung oleh pendapat Jatmika et al. (2019), bahwa media audiovisual memiliki beberapa manfaat, diantaranya yaitu memudahkan seseorang dalam mengingat, menggunakan gambar yang membuat seseorang lebih fokus, gambar juga dapat mempengaruhi emosional pembaca. Media visual tersebut diantaranya yaitu televisi, video, dan film.

eee..kalau saya lebih ke yang video ya karena lebih sederhana dan mengena (Ny.AA, 36 tahun)

Jenis media promosi yang dipilih untuk mendapat informasi kesehatan terbanyak adalah media sosial (75,3\%) seperti halnya yang diungkapkan tenaga kesehatan Puskesmas Depok II yang sudah menggunakan instagram dan whatsapp sebagai media promosi kesehatan.

Kalau untuk media sosial sendiri sebenernya kita juga sudah memanfaatkan Instagram..kadang kita juga live Instagram untuk tanya jawab ke warga sekitar. Kita di promkes juga membuat membuat media promosi selebaran apa ya poster terus kita share di grup whatsapp desa, RW atau dukuh dan kader (Ny.BS, 25 tahun)

Hal ini didukung oleh pendapat Bacigalupe (2011) yang menyebutkan bahwa media sosial dapat melengkapi promosi kesehatan yang masih konvensional sehingga meningkatkan akses masyarakat untuk mendapatkan informasi kesehatan serta mempromosikan perubahan perilaku yang positif. Media sosial memiliki kelebihan untuk memfasilitasi masyarakat agar memperoleh pengetahuan yang lebih baik tentang penyakit dan pencegahannya, bisa menggunakan layanan kesehatan yang lebih baik serta memiliki kepatuhan terhadap pengobatan dan tingkat partisipasi yang lebih baik (Ortega-Navas, 2017; Welch et al., 2018).

Namun demikian, Leonita \& Jalinus (2018) mengingatkan bahwa media sosial juga memiliki kelemahan yaitu kurangnya penjangkauan terhadap audiens pasif, informasi palsu dan tidak akurat, kurangnya interaksi dengan audiens, serta keterbatasan kemampuan teanaga kesehatan untuk memanfaatkan media sosial sehingga keberlanjutan program tidak dapat dijamin. Oleh karena itu, tenaga kesehatan perlu untuk merancang media promosi kesehatan berbasis media sosial yang mengintegrasikan media tersebut dengan strategi promosi kesehatan serta strategi komunikasi kesehatan.

\section{KESIMPULAN}

1. Media promosi kesehatan tentang layanan PITC bagi ibu hamil diperlukan dengan tujuan untuk mempermudah penyampaian informasi dan pemahaman ibu hamil.

2. Segmentasi sasaran media promosi layanan PITC adalah suami dan ibu hamil, serta keluarga yang tinggal bersama ibu hamil dengan cara penyampaian informasi kesehatan yang paling efektif dilakukan secara individu.

3. Posisi pesan (positioning) tentang layanan PITC yang dibutuhkan yaitu pengertian, manfaat, cara memanfaatkan dan tahapan layanan PITC dengan bentuk pesan yang lebih mudah dipahami adalah berupa gambar, tulisan dan suara.

4. Strategi positioning adalah media selebaran dan video dengan alasan ketertarikan membaca karena manfaat yang disampaikan penting.

5. Media promosi kesehatan yang paling mudah dipahami adalah media yang 
Analisis Kebutuhan Media Promosi Kesehatan...

dapat didengar dan dilihat
(audiovisual), sedangkan jenis media promosi yang dipilih untuk mendapat informasi kesehatan terbanyak adalah media sosial.

\section{SARAN}

1. Bagi pengelola program promosi kesehatan di Puskesmas maupun Dinas Kesehatan direkomendasikan untuk merancang media promosi kesehatan tentang layanan PITC bagi ibu hamil berupa media sosial yang dapat diakses secara individu serta mengintegrasikan media tersebut dengan strategi promosi kesehatan serta strategi komunikasi kesehatan.

2. Bagi penelitian selanjutnya disarankan untuk mengembangkan penelitian kerjasama dengan pengelola program di Puskesmas maupun Dinas Kesehatan untuk merancang media promosi tentang layanan PITC bagi ibu hamil yang berisi pesan tentang pengertian, manfaat, cara memanfaatkan dan tahapan layanan PITC dengan bentuk pesan yang lebih mudah dipahami adalah berupa gambar, tulisan dan suara (audiovisual).

\section{UCAPAN TERIMA KASIH}

Ucapan terima kasih kepada Direktur Riset dan Pengabdian Masyarakat Kementerian Riset dan Teknologi/Badan Riset Inovasi Nasional sebagai pemberi dana penelitian dosen pemula tahun 2020 .

\section{DAFTAR PUSTAKA}

Abtew, S., Awoke, W., \& Asrat, A. (2016). Knowledge of pregnant women on mother-to-child transmission of HIV, its prevention, and associated factors in Assosa town, Northwest Ethiopia. HIVIAIDS (Auckland, N.Z.), 8, 101-107. https://doi.org/10.2147/HIV.S100301

Agustini, A. (2014). Promosi Kesehatan. Deepublish. https:// penerbitbukudeepublish.com/shop/ buku-promosi-kesehatan/

Ahmadi, F., \& Ibda, H. (2018). Media Literasi Sekolah: Teori dan Praktik (D. M. Wijayanti (ed.)). CV. Pilar Nusantara.

Ajzen, I., Joyce, N., Sheikh, S., \& Cote, N. G. (2011). Knowledge and the Prediction of Behavior: The Role of Information Accuracy in the Theory of Planned Behavior. Basic and Applied Social Psychology, 33(2), 101-117. https://doi.org/ 10.1080/01973533.2011.568834

Bacigalupe, G. (2011). Is there a role for social technologies in collaborative healthcare? Families, Systems $\mathcal{E}$ Health: The Journal of Collaborative Family Healthcare, 29(1), 1-14. https:// doi.org/10.1037/a0022093

Dinkes DIY. (2019). Profil Kesehatan Tahun 2019 Kota Yogyakarta. https:// kesehatan.jogjakota.go.id/uploads/ dokumen/ profil_dinkes_2019_data_2018.pdf

Dinkes DIY. (2020). Profil Kesehatan DIY Tahun 2019. http:// dinkes.jogjaprov.go.id/download/ download/82

Humas DIY. (2019). Penanggulangan AIDS Jadi Kewajiban Bersama.

Jogjaprov.Go.Id. https:// jogjaprov.go.id/berita/detail/8351penanggulangan-aids-jadi-kewajibanbersama

Jatmika, S. E. D., Maulana, M., Kuntoro, \& Martini, S. (2019). Buku Ajar Pengembangan Media Promosi Kesehatan (E. Khuzaimah (ed.)). Penerbit KMedia. http://eprints.uad.ac.id/ 15793/1/Buku Ajar Pengembangan Media Promosi Kesehatan.pdf

Kemenkes RI. (2020). Rencana Aksi Nasional Pencegahan Penularan HIV dari Ibu ke Anak (PPIA) di Indonesia 2015-2019. Kementerian Kesehatan RI. https://siha.kemkes.go.id/portal/ files_upload/

RAN_HIV_Health_Sector_Action_Pla n_2015_2019_FINAL_070615_.pdf 
Korda, H., \& Itani, Z. (2013). Harnessing social media for health promotion and behavior change. Health Promotion Practice, 14(1), 15-23. https://doi.org/ 10.1177/1524839911405850

Leonita, E., \& Jalinus, N. (2018). Peran Media Sosial Dalam Upaya Promosi Kesehatan: Tinjauan Literatur. INVOTEK: Jurnal Inovasi Vokasional Dan Teknologi, 18(2), 25-34. https:// doi.org/10.24036/invotek.v18i2.261

Notoatmodjo, S. (2010). Promosi Kesehatan Teori dan Aplikasi. Rineka Cipta.

Novika, A. G., \& Setyaningsih, D. (2019). Pelaksanaan Layanan Screening HIV AIDS pada Ibu Hamil di Banguntapan Bantul. Prosiding Seminar Nasional Universitas Respati Yogyakarta. Seminar Nasional UNRIYO November 2019. http:// prosiding.respati.ac.id/index.php/ PSN/article/view/205/199

Ortega-Navas, M. del C. (2017). The use of New Technologies as a Tool for the Promotion of Health Education. Procedia - Social and Behavioral Sciences, 237, 23-29. https://doi.org/10.1016/ j.sbspro.2017.02.006

Pudjiati, S. R. (2016). Peran Tenaga Kesehatan dalam Meningkatkan Cakupan Tes HIV Dini. Kebijakanaidsindonesia.Net. https:// www.kebijakanaidsindonesia.net/id/ artikel/artikel-tematik/1454-perantenaga-kesehatan-dalammeningkatkan-cakupan-tes-hiv-dini
Rokom Redaksi Sehat Negeriku. (2019). Hari HIVIAIDS Sedunia, Penanganan Diperkuat di Daerah. Sehatnegeriku.Kemkes.Go.Id. https:// sehatnegeriku.kemkes.go.id/baca/ rilis-media/20191129/0532400/harihivaids-sedunia-penanganandiperkuat-daerah/\#: :text=Upaya pencegahan dan pengendalian HIV -AIDS bertujuan untuk mewujudkan target,HIV\%2FAIDS (ODHA)

Siregar, P. A., Harahap, R. A., \& Aidha, Z. (2020). Promosi Kesehatan Lanjutan Dalam Teori Dan Aplikasi. Kencana Prenada Media Group. http:// repository.uinsu.ac.id/id/eprint/9183

Sumitri, S., \& Darmayanti, D. (2019). Hambatan Deteksi Dini HIV/AIDS pada Ibu Hamil. SEAJOM: The Southeast Asia Journal of Midwifery, 3(2), 20-26. https://doi.org/10.36749/ seajom.v3i2.10

Welch, V., Petkovic, J., Simeon, R., Presseau, J., Gagnon, D., Hossain, A., Pardo Pardo, J., Pottie, K., Rader, T., Sokolovski, A., Yoganathan, M., Tugwell, P., \& DesMeules, M. (2018). Interactive social media interventions for health behaviour change, health outcomes, and health equity in the adult population. Cochrane Database of Systematic Reviews, 2018(2). https:// doi.org/10.1002/14651858.CD012932

WHO. (2015). Mother to Child Transmission of HIV. Who.Int. https://www.who.int/ hiv/topics/mtct/about/en/ 